\title{
Paradigma Teori Atom Lintas Waktu
}

\author{
Sujito ${ }^{1}$, Sunardi $^{2)}$, Ma'ruf $^{3)}$, Sri Hartini ${ }^{4}$ \\ ${ }^{1)}$ Fisika FMIPA Universitas Negeri Malang \\ ${ }^{1,2)}$ Mahasiswa Program Studi Doktor Pendidikan IPA Universitas Pendidikan IPA \\ ${ }^{3)}$ Program Studi Pendidikan Fisika Universitas Muhammadiyah Makasar \\ ${ }^{4)}$ Program Studi Pendidikan Fisika Universitas Lambung Mangkurat \\ e-mail: Sujito.fmipa@um.ac.id; sujito@upi.edu,Sunardi1432@gmail.com
}

\begin{abstract}
Abstrak
Teori atom merupakan teori yang dinamis dan terus berkembang sesuai dengan temuan perkembangan ilmu pengetahuan dan teknologi. Hasil penemuan dan pemikiran tentang membawa dampak yang cukup beragam bagi perkembangan manusia itu sendiri. Manusia dengan menggunakan nalarnya berusaha untuk menemukan hal-hal baru yang berpatokan filosofi. Pemikiran manusia tidak akan terlepas dari pandangan ontologis, epistemologis, aksiologis dan metodologis. Hasil pemikiran tersebut akan menimbulkan anomali atau penyimpangan dari umum. Akumulasi dari anomali-anomali tersebut akan menghasilkan revolusi sains. Sesuai dengan pemikiran Thomas Kun bahwa Sains (IImu Pengetahuan Alam) tidak selalu bersifat akumulatif, sehingga revolusi sains akan menyebabkan terjadinya perubahan paradigma baru. Perubahan paradigma tentang teori atom berangkat dari pemikiran yang dogmatis, kemudian terjadi terobosan-terobosan baru dalam revolusi sains. Ide-ide gila munculnya lagi dengan ditemukannya teori Mekanika Kuantum. Hal ini yang melatarbelakangi munculnya annihilasi materi yang berkembang menjadi teori penyusun atas materi dan segala sesuatu. Revolusi kuantum memberikan kesadaran pada umat manusia tentang kesesaran Tuhan yang luar biasa. Dengan kekuasaannya Tuhan menciptakan otak dan pikiran yang menyala menjadi berkah bagi manusia untuk meramal yang llahiyah menerobos misteri ciptaanNya sendiri.
\end{abstract}

Kata Kunci: Atom, Klasik, Kuantum, Paradigma, Tuhan

\begin{abstract}
Atomic theory is a dynamic theory and continues to develop in accordance with the findings of the development of science and technology. The findings and thoughts about the effects those are quite diverse for human development itself. Humans using their reasoning try to find new things that are based on philosophy. Human thinking will not be separated from ontological, epistemological, axiological and methodological views. The results of these thoughts will cause anomalies or deviations from the public. The accumulation of these anomalies will result in a scientific revolution. In accordance with Thomas Kun's idea that Science (Natural Sciences) is not always accumulative, so the scientific revolution will cause a new paradigm change. The paradigm shift about atomic theory departs from dogmatic thinking, and then new breakthroughs occur in the scientific revolution. Crazy ideas arise again with the discovery of the theory of quantum mechanics. This is the background of the emergence of annihilation of material which developed into a theory of the compilation of matter and everything. The quantum revolution gives awareness to mankind about the extraordinary greatness of God. With his power, God created the brain and mind that is burning into a blessing for humans to predict the Divine through the mystery of His own creation.
\end{abstract}

Keywords : Atom, Classic, Quantum, Paradigm, God 


\section{Pendahuluan}

Paradigma merupakan suatu pandangan mendasar dari suatu disiplin ilmu tentang apa yang menjadi pokok permasalahan yang mesti dipelajari. Paradigma membantu manusia untuk merumuskan mengenai apa yang terjadi dan harus dipelajari, permasalahan yang harus dijawab dan bagaimana jawaban dibangun berdasarkan persoalan, dan aturan-aturan yang harus diikuti dalam mengintepretasikan fenomena atau fakta informasi yang terkumpul. Tiga elemen utama yang menjadi isu-isu dasar dan menjadi bagian isu pokok paradigma, yaitu aspek ontologis, epistemologi dan metodologis (Poedjiadi, 1987). Berdasarkan tiga elemen utama ini maka manusia mengenal dunia dan fenomena-fenomena yang terjadi di alam sekitar. Dalam artikel ini mengkaji fenomena teori atom berdasarkan pandangan epistemolog.

Teor Model Atom yaitu susunan zat sudah menjadi perhatian sejak 2500 tahun yang lalu, yaitu sejak jaman yunani kuno. Pendapat ini lebih dikembangkan lagi pada masa Leucippus dan Demokritus yang menyatakan bahwa sesuatu zat tidak dapat dibelah terus menerus tanpa batas, ada bagian yang paling kecil yang tidak dapat dibagi-bagi atau dibelah lagi, itu yang mereka sebut "atomos" yang artinya yang tidak dapat dibagi-bagi lagi. Sebaliknya Aristoteles berpendapat partikel dapat dibelah terus menerus tanpa batas (Sabarni ,2014).

Pemikiran konsep atom zaman yunani yaitu dalam memikirkan alam semesta, Sebagian besar para ahli filsafat Yunani meninjaunya dalam skala makro, yaitu berdasarkan apa yang mereka lihat secara kasat mata saja. Namun ada pula beberapa ahli filsafat yang memikirkan lebih jauh makna terdalam dari jagat raya ini dalam konsep berskala mikro, artinya berpikir secara abstrak hal-hal yang tidak dapat mereka lihat namun mereka yakini keberadaannya, mereka disebut para atomist (Farida ,2011). Teori atom merupakan salah satu teori dalam Fisika Inti (Nuclear) yang mendasarkan kajiannya pada permasalahan ini. Fisika Inti (Nuclear) merupakan matakuliah yang menjelaskan teori atom secara menyeluruh sesuai dengan perkembangan mulai zaman pra sejarah sampai modern. Salah satu konsep yang mengalami perubahan secara dinamis adalah mengenai konsep atom. Kajian teori-teori dan pemodelan yang dikembangkan mempunyai manfaat yang luas dalam menerangkan gejala-gejala fisis dan kimia. Selain itu, penemuan-penemuan baru partikel materi penyusun dari atom mengakibatkan luasnya penerapan implikasi berdasarkan temuan yang baru.

Seiring dengan perkembangan ilmu pengetahuan dan teknologi, penerapan hasil-hasil pemikiran dan penemuan tentang konsep teori atom menjangkau segala bidang. Hal ini membawa dampak yang fenomenala dalam kehidupan manusia. Selain membawa dampak yang positif bagi kesejahteraan umat manusia, juga berdampak negatif dan berpotensi untuk membawa kesengsaraan bagi masyarakat. Seperti penemuan bom atom yang diujicoba ke Nagasaki dan Hiroshima oleh tentara Amerika Serikat pada waktu perang dunia ke-2. Manusia menggunakan teknologi karena memiliki akal. Dengan akalnya manusia ingin keluar dari masalah, ingin hidup lebih baik, lebih aman, dan sebagainya. Perkembangan teknologi terjadi karena seseorang menggunakan akalnya untuk menyelesaikan setiap masalah yang dihadapinya (Ngafifi ,2014).

Berdasarkan paradigma epistemologi dan kerangka berpikir Kuhn dalam artikel ini menyajikan analisis perkembangan mengenai yang berkembang tentang teori atom. Artikel ini mendasarkan pada artikel Thomas Kuhn (1993) yang menjelaskan sains (Ilmu Pengetahuan Alam/IPA) tidak selalu bersifat akumulatif, tapi kadang parsial (Kuhn, 1993). Revolusi sains akan mengubah paradigma jika paradigm baru ditemukan sehingga hal ini akan mengubah kemapanan teori sains. Periode sains mapan, Ilmuwan akan bekerja untuk memverifikasi dan menguji teori-teori berdasarkan temuan-temuan yang ditemukan setelah teori mapan.

Pada tahap atau periode ini temuan baru akan dianggap sebagai sebuah anomali atau penyimpangan hasil diabaikan karena menyimpang dari kewajaran saat itu. Akan tetapi, kumpulan anomali-anomali memungkinkan terjadi krisis paradigma, sehingga sains normal tidak dapat berlanjut. Maka, pada saat ini akan muncul revolusi sains dan muncul paradigma baru. Paradigma baru yang muncul setelah anomali akan tetap bertahan, jika hasil verifikasi atau fakta-fakta dapat mendukungnya. Semakin banyak yang melakukan verifikasi terhadap paradigma semakin kuat kedudukannya, pada akhirnya dapat menjadi sains yang normal. Kedepan, jika terjadi anomali yang terakumulasi, maka akan terjadi lagi krisis paradigma yang menjadi penyebab revolusi sains baru berikutnya. 


\section{Metode}

Metode yang digunakan dalam penulisan artikel ini adalah studi pustaka. Adapun pendekatan yang digunakan adalah paradigma ontologis, epistemology, aksiologi dan kerangka berpikir Kuhn. Secara ontologis mempertanyakan kebenaran dari sesuatu keberadaan teori atom (Poedjiadi, 1987). Menjawab sebuah pertanyaan "Bagaimana realitas sebenarnya tentang teori atom" menjadi pembahasan yang universal. Begitu juga pemikiran manusia. Aspek aksiologi adalah mengambil manfaat atau kegunaan dari teori atom dalam perkembangan ilmu pengetahuan dan teknologi serta untuk apa pengetahuan tersebut dipergunakan (Kuhn, 1993). Pembahasan mengenai teori atom dalam penulisan artikel ini dimaksudkan untuk menganalisis dan menginterpretasi fenomena-fenomena dalam ilmu eksak terkait dengan perkembangan teori partikel. Pembahasan dalam penulisan ini berdasarkan sejarah perkembangan teori atom mengacu pada kerangka berpikir yang dikemukakan Kuhn (1993) dalam karyanya The Structure of Scientific Revolutions.

Aspek Epistemologi teori atom memandang teori atom berdasarkan cara-cara menemukan dan mengarahkan teori atom (Dampier, 1984). Suatu missal adalah mengambil ontologis yang dikemukan oleh Democritus "atom tidak dapat dibagi?" Ini mengandung dua interpretasi jawaban; pertama, tidak mungkin secara fisika untuk membagi suatu atom; kedua, tidak mungkin secara logis dan konseptual untuk membagi suatu atom. Perbedaan kedua penafsiran masing-masing mengandung konsekuensi, yaitu pada pertama, sebuah atom masih mungkin mempunyai bagian yang lebih kecil, sedangkan pada kedua, tidak ada bagian suatu atom. Kalau bermaksud membagi atom menjadi bagian yang lebih kecil, maka akan mendapatkan ketidakmampuannya bukan dari sisi teknologi, tapi konseptual. Atom bukan hanya sangat kecil, tetapi atom merupakan partikel terkecil, dan bukan hanya terlalu kecil untuk dibagi secara fisis tetapi juga tidak bisa dibagi secara logis.

\section{Hasil dan Pembahasan}

\section{Dogmatisme Teori Atom}

Dalam memikirkan alam semesta, ahli filsafat Yunani mengembangkan pada skala makro, yaitu mendasarkan apa yang mereka lihat secara kasat mata. Namun, ada pula ahli filsafat yang mengembangkan pemikirannya lebih jauh makna terdalam dalam konsep berskala mikro. Ini berarti berpikir secara abstrak terhadap hal-hal yang tidak dapat dilihat, namun diyakini keberadaannya. Pertama yang menyampaikan teori atom adalah Leucippus dari Miletus-Yunani (440 SM) dan Democritus dari Abdera (420 SM) (Stephen F, 1992). Pada hakekatnya gagasan Leucippus dan Democritos mengenai materi yang bersifat diskontinu. Materi tersusun dari partikel-partikel kecil yang tidak dapat dibagi-bagi lagi yang diketahui sebagai atom. Atom-atom penyusun materi itu senantiasa bergerak di dalam kehampaan (Feinberg, 1990). Istilah atomos diberikan terhadap partikel materi itu, karena atom-atom sangat halus dan tidak dapat dibagi-bagi lagi (Bruton, 1996). Lucretius, salah satu penyair terbaik dari Roma pada abad itu, mempercayai konsep atom tersebut. la meninggalkan sebuah deskripsi mengenai hal itu dalam puisi yang panjang, yaitu De Rerum Natura ('On the nature thing'). la mempunyai pandangan bahwa suatu kesatuan tubuh yang tampaknya tidak terpecah-pecah sebenarnya dihasilkan oleh kumpulan atom yang berukuran sangat kecil (Bernal, 1981; Bruton, 1996).

Para ahli fisafat alam seperti Aristoteles (384-322 SM) dari Staigera Yunani, Plato dan Galen (130-200 SM) menolak konsep atom tersebut (Bruton, 1996; Dampier, 1984; Keenan, 1980). Mereka menolak karena berpandangan bahwa materi merupakan satu kesatuan yang utuh (kontinu) dapat dibagi menjadi bagian sekecil-kecilnya tanpa batas dan tidak ada kehampaan di alam semesta (ruang hampa). Jagad raya terdiri dari 4 elemen penyusun, yaitu tanah, api, udara dan air (Kuhn, 1993; Stephen F, 1992). Pandangan mereka diperkuat oleh Thales dari Miletus (sekitar 580 tahun SM), Anaximenes (550-475 SM) dan Anaximander (tahun 610-545 SM) (Poedjiadi, 1987; Stephen F, 1992). Pendapat filsuf terutama Aristoteles lebih diyakini dan dipercaya masyarakat karena popularitas dan kredibilitasnya. Pendapat tersebut berlangsung cukup lama hingga sampai abad pertengahan (27 SM- $476 \mathrm{M}$ ) atau abad kegelapan Eropa (Musthafa, 2000). Aristoteles dianggap sebagai filsuf Yunani yang terbaik. Gagasannya sangat luas dalam berbagai bidang dan dituliskannya dalam bentuk buku yang berkaitan dengan perkembangan pengetahuan seperti astronomi, biologi, metafisika, hukum, politik, logika, etika dan estetika. 
Pada abad kegelapan di Eropa, perkembangan sains dan teknologi mengalami hambatan. Hal ini, karena saat itu pemikiran para ilmuwan, terkungkung oleh ajaran agama Katolik ortodoks, yang mengikat kebebasan berpikir tentang keduniawian, terutama ilmu pengetahuan (Bruton, 1996). Pemikiran yang nampaknya bertentangan dengan "ajaran" agama, dianggap sebagai kesalahan dan dosa yang harus ditebus dengan hukuman fisik bahkan dengan nyawa. Paradigma Aristotelian masih diakui, karena dianggap tidak bertentangan dengan "ajaran" agama. Selain konsep atom yang mendapat pembenaran dari ajaran agama, gagasan lainnya adalah mengenai konsep geosentris dan penolakan terhadap konsep ruang vakum (Dampier, 1984).

Ketika di Eropa mengalami kegelapan, di Timur (Timur Tengah) mengalami kemajuan dalam ilmu pengetahuan dan teknologi. Perkembangan ilmu pengetahuan dan teknologi di Timur Tengah tumbuh dan berkembang dengan pesat. Ilmuwan muslim dari Timur Tengah yang menyinggung masalah atom adalah Abul Hasan Al Asy'ari (873-935 M) (Musthafa, 2000). la mengkaitkannya dengan masalah kejadian alam semesta. la berpendapat bahwa alam semesta ini maujud karena adanya atom-atom yang menyusunnya. Atom-atom itu sudah mempunyai sifat sendiri (eigen natuur) dan tidak padat berkembang, serta tidak bisa saling mempengaruhi. Jadi menurutnya, atom-atom yang menyusun alam semesta tidak dapat berubah (Dampier, 1984). Atom-atom dipisahkan satu sama lain oleh ruang antara dan satu sama lain tidak dapat saling mempengaruhi. Perubahan yang terjadi di alam semesta, terjadi karena atom-atom senantiasa "keluar-masuk" dari eksistensi (alam 'ada'). Berdasarkan keyakinannya terhadap Allah SWT, ia meyakini bahwa "masuk" artinya diciptakan Tuhan dan "keluar" berarti ditiadakan Tuhan. Jadi menurutnya, atom-atom itu selalu harus diciptakan Tuhan setiap saat untuk menggantikan atom-atom yang sudah ditiadakannya (Musthafa, 2000).

Pandangan tersebut hampir bersesuaian dengan Leucippus maupun Democritus karena mengakui adanya sifat diskontinu dari materi. Namun tampak Abul Hasan Al-Asy'ari ini menolak anggapan bahwa perubahan alam semesta disebabkan oleh hukum alam yang pasti serta tunduk pada hukum "sebab-akibat" yang melekat pada perilaku atom-atom. Sejauh ini sumbangan pemikiran mengenai konsep atom dari ilmuwan dunia Arab atau muslim tidak banyak ditemukan, karena keterbatasan pencarian literatur yang relevan. Mungkin saja terdapat pemikiran yang lebih maju mengenai konsep atom dan hal-hal yang berkaitan dengan itu. Mengingat pada ahir abad pertengahan literatur dari dunia Arab banyak yang dimusnahkan, akibat serangan pasukan Hulagu Khan dari Mongol pada tahun 1258 yang menghancurleburkan Bagdad yang menjadi pusat kebudayaan Islam (Musthafa, 2000).

Namun demikian, tinjauan teori atom menurut Abul Hasan Al-Asy'ari ternyata memperkuat keberadaan gagasan konsep Atom Leucippus dan Democritus. Misalnya, pembenaran terhadap konsep heliosentris yang dikemukakan oleh beberapa ilmuwan utama abad ke-17, seperti Galileo, Newton dan ilmuwan abad sebelumnya. Konsep atom semakin kuat kedudukannya pada permulaan abad-19 setelah pemikiran ini didukung hasil temuan melalui pengamatan dan eksperimen yang dilakukan ilmuwan. Pada periode ini diletakkan suatu pandangan baru untuk menjelaskan sifat-sifat fisika dari keadaan zat padat, gas dan cair serta mengidentifikasikan fakta-fakta penggabungan kimiawi secara kuantitatif.

\section{Terobosan Revolusi Sains Modern}

Sir Isac Newton adalah seorang pria kebangsaan inggris merupakan peletak dasar-dasar fisika klasik yang pada waktu itu dianggap telah dapat menerangkan seluruh gejala fisis dengan hukum-hukumnya (Bruton, 1996; Stephen F, 1992) Hampir 300 tahun sebelum reformasi kuantum, hukum-hukum Newton dianggap sebagai hukum-hukum dasar fisika. Dalam rentang waktu itu, hukum-hukum Newton tak terbantahkan dan tak ada satupun yang dapat ditambahkan kepadanya. Sifat partikel dari cahaya diterima luas. Konsekwensinya, menentang teori bahwa cahaya adalah semata gelombang, yang diajukan oleh fisikawan Belanda, Huygens. Partikel dan gelombang pada cahaya menjadi perdebatan sengit para fisikawan saat itu, bahkan sampai sekarang. Newton telah meramalkan bahwa cahaya, yang berjalan dengan kecepatan 186.000 mil per detik ( $\pm 300.000 \mathrm{~km} /$ detik) di ruang hampa, seharusnya berjalan lebih cepat dalam air (Dampier, 1984; Stephen F, 1992). Teori gelombang cahaya akan mematahkan ramalan ini.

Temuan baru mengenai gejala kelistrikan mengubah paradigma bahwa atom merupakan partikel bagian terkecil dari materi, karena dapat dibuktikan adanya partikel sub atom seperti proton, elektron dan netron. Beberapa studi yang intensif yang dilakukan membawa ke dalam suatu babak baru penyelidikan mengenai atom yang membawa pemahaman yang sangat berbeda dengan pandangan filosofi Dalton. Beberapa penemuan yang menyebabkan terjadinya 
revolusi pemikiran atom elektrolisis, sifat kelistrikan atom dan penemuan partikel sub-atom, gejala keradioaktifan, eksperimen rutherford, dan nomor atom dan isotop (Hodeson, 2012; Stephen F, 1992)

Terobosan besar untuk teori gelombang dicapai oleh ilmuwan cemerlang dari Skotlandia James Clerk Maxwell, pada paruh kedua abad ke-19 (Stephen F, 1992). Maxwell mendasarkan dirinya pada kerja eksperimental dari Michael Faraday, yang menemukan induksi elektromagnet, dan menyelidiki sifat-sifat magnet, dengan kedua kutubnya, utara dan selatan, yang melibatkan gaya-gaya tak kasat mata yang membentang di bumi dari ujung ke ujung. Persamaan matematis Maxwell ini kemudian memantapkan relasi listrik-magnet dalam empat persamaan fundamen yang mengaturnya (Mc Avoy \& Zarate, 1996). Karya Maxwell ini membimbing orang ke dalam penemuan medan, yang kemudian menjadi dasar Einstein untuk merumuskan teori relativitas umumnya. Disinilah munculnya revolusi sains baru. Satu generasi berdiri di atas bahu generasi sebelumnya. Saling menegasi, memperkaya, dan memelihara penemuan yang terdahulu. Terus-menerus mendalaminya, dan memberinya bentuk-bentuk dan hakikat yang lebih umum.

Setelah meninggalnya Maxwell, Hertz mendeteksi untuk pertama kalinya gelombang elektromagnetik yang diramalkan oleh Maxwell (Hayashi, 2017). Teori partikel, yang telah berkuasa sejak Newton, nampaknya dihantam hancur oleh elektromagnetika Maxwell. Sekali lagi para ilmuwan percaya bahwa mereka telah menggenggam satu teori yang akan dapat menjelaskan segala sesuatu. Ada anomali pada saat itu, beberapa ketidakcocokan yang mengganggu, tapi nampaknya cukup kecil sehingga dapat diabaikan. Beberapa dasawarsa kemudian, beberapa ketidakcocokan "kecil" ini terbukti cukup untuk menggulingkan seluruh struktur teori yang ada dan mendorong terjadinya revolusi ilmiah yang kuat. Terobosan penemuan-penemuan modern mengakibatkan munculnya berbagai teori modern mengenai teori atom. Diawali dari temuan Plank yang dipecahakan oleh Bohr hingga penemuan dualisme gelombang partikel mendorong munculnya teori terbaru.

\section{Antara Partikel dan Gelombang}

Aplikasi dari teori kuantum Planck untuk memecahkan masalah struktur atom pertama kali dilakukan oleh Niels Bohr (1885-1962) pada tahun 1913 ilmuwan dari Copenhagen yang ketika itu bekerja di Rutherford"s Laboratory di Manchester (Dampier, 1984). la bekerja berdasarkan teori planet elektron yang mendapat banyak penolakan oleh ilmuwan fisika. Tujuan pekerjaan Bohr ini adalah mencari keterangan baru bagaimana posisi elektron di sekeliling atom. Niels Bohr memulainya dengan mempelajari secara intensif spektrum atom (khususnya spektrum atom hidrogen) dan menerapkan teori kuantum Max Planck untuk menjelaskannya. Konsep-konsep yang mendukung teori atom Bohr adalah spektrum atom, teori kuantum radiasi Planck dan Einstein, dan radiasi gelombang elektromagnetik (Hodeson, 2012).

Gelombang di permukaan air akan menyebabkan satu objek yang sedang mengapung terangkat naik-turun, lebih cepat atau lebih lambat, tergantung kekuatan gelombang itu sendiri. Riak yang disebabkan oleh seekor bebek tentu jauh lebih lemah daripada yang disebabkan oleh sebuah kapal motor. Mirip dengan itu, osilasi elektron akan berbanding lurus dengan intensitas gelombang cahaya. Persamaan Maxwell, yang telah didukung oleh Hertz dan lain-lain, menyediakan satu bukti yang kuat untuk mendukung teori bahwa cahaya merupakan gelombang, yang memiliki sifat-sifat elektromagnetik. Walau demikian, sampai pada peralihan abad, bukti-bukti masih kurang memadai. Tahun 1900 Max Planck menunjukkan bahwa teori gelombang klasik membuat beberapa ramalan yang tak dapat dibuktikan dalam praktek. Salah satunya adalah radiasi yang dihasilkan benda hitam (black body) (Hayashi, 2017). la mengajukan bahwa cahaya datang dalam partikel-partikel diskret atau dalam "paket-paket" (kuanta).

Situasinya menjadi lebih rumit lagi oleh adanya fakta bahwa percobaan-percobaan lain membuktikan hal-hal yang bertentangan. Pada eksperimen celah ganda, dapat dikatakan bahwa elektron mempunyai sifat partikel dan gelombang sekaligus. Elektron dipandang sebagai partikel, ditembakkan satu persatu melewati celah ganda dan kemudian menumbuk layar pelat fotografis. Hasilnya adalah pola yang dibentuk pada plat itu. Polanya adalah gelap terang, yang merupakan sifat khas dari gelombang yang berinterferensi. Pertanyaan selanjutnya, apakah lintasan eleketron sebelum menumbuk plat itu bergejala layaknya gelombang? lalu, celah mana yang dilewati? apakah elektron itu melewati kedua celah dalam waktu yang bersamaan tanpa membelah dirinya? Ini tentunya bertentangan dengan hukum-hukum nalar sehat, tapi percobaan ini tak dapat dibantah lagi kebenarannya. Sebuah elektron bersifat baik sebagai 
partikel maupun sebagai gelombang. la berada dalam dua (atau lebih) tempat sekaligus, dan dalam beberapa keadaan gerak sekaligus.

Banesh Hoffmann memandang bahwa para ilmuwan menerima penemuan baru ini dengan sorak kemenangan (Musthafa, 2000). Ilmuwan menentang penemuan-penemuan ini dan menolaknya sejauh mereka dapat, menciptakan segala jenis jebakan dan hipotesis alternatif dalam sebuah upaya putus asa untuk menyelamatkan diri dari keharusan menerima fakta itu sebagai kebenaran. Tapi paradoks itu telah hadir dengan menyolok sejak 1905 dalam kasus cahaya. Teori tersebut bertahan sampai munculnya mekanika kuantum yang baru itu. Ide baru ini sangatlah sulit diterima. Secara terus menerus insting berusaha membangun gambaran tentangnya dalam bentuk-bentuk partikel tradisional, dengan mengabaikan prinsip ketidakpastian Heisenberg (Aoki, Endrodi, Fodor, Katz, \& Szabo, 2006). Ilmuwan masa ini terus menghindar dari penggambaran sebuah elektron sebagai sesuatu yang memiliki gerak, mungkin tidak memiliki posisi, dan sembari memiliki posisi, mungkin tidak mengenal konsep gerak atau diam. Dalam hal ini, melihat bekerjanya negasi dari negasi. Pada pandangan pertama, terlihat sepertinya telah menempuh satu lingkaran penuh. Teori partikel cahaya dari Newton telah dinegasi oleh teori gelombang Maxwell.

Teori ini, pada gilirannya, dinegasi pula oleh teori partikel yang baru, yang dikemukakan oleh Planck dan Einstein. Namun, bukan berarti kembali pada teori Newtonian lama, tapi menempuh lompatan kualitatif ke depan, dengan melibatkan satu revolusi sejati dalam ilmu pengetahuan. Semua ilmu pengetahuan harus dirombak total, termasuk hukum gravitasi Newton itu sendiri. Revolusi ini tidaklah membuat persamaan Maxwell tidak berlaku lagi, persamaan itu tetap sahih untuk sejumlah besar operasi tentang medan. Yang ditunjukkan hanyalah, di luar batas tertentu, ide-ide fisika klasik tidak lagi berlaku. Gejala dunia partikel subatomik tidaklah dapat dipahami dengan metode-metode mekanika klasik. Ide-ide mekanika kuantum dan relativitas bermain penuh. Pada sebagian besar waktu di abad ini, fisika telah didominasi oleh teori relativitas dan mekanika kuantum yang, pada awalnya, ditolak mentahmentah oleh orang-orang yang mendominasi ilmu pengetahuan, yang berpegangan erat-erat pada pandangan klasik. Ada pelajaran yang penting di sini. Upaya apapun untuk memaksakan satu "solusi final" terhadap pandangan atas jagad raya ini pasti akan menemui kegagalan.

\section{Mekanika Kuantum}

Perkembangan fisika kuantum merupakan lompatan besar ke muka dalam ilmu pengetahuan. Konsep determinisme yang menjadi tonggak fisika klasik mulai akan roboh. Sebagai gantinya, didapatkan satu pandangan atas alam yang lebih lentur dan dinamis. Dimulai dengan penemuan Max Planck tentang keberadaan kuantum, yang pada awalnya terlihat sebagai sebuah rincian yang tak masuk akal, remeh, dan hampir seperti sebuah anekdot, seluruh wajah fisika mengalami perubahan (Hayashi, 2017). Dari sini didapatkan sebuah ilmu pengetahuan baru yang dapat menjelaskan gejala peluruhan radioaktif dan menelaah dengan sangat rinci data spektroskopi unsur-unsur yang kompleks itu. Fisika baru telah mengungkap kekuatan maha dahsyat yang tersimpan dalam inti atom (Trefil, 1990).

Hal ini membawa dampak secara langsung pada penyalahgunaan energi nuklir -jalur yang penuh potensi pengrusakan atas kehidupan di muka bumi- atau justru pada masa depan yang sampai sekarang tak berani dibayangkan orang, dengan kelimpahan tanpa batas dan kemajuan sosial melalui penggunaan fusi nuklir secara damai. Teori relativitas Einstein menjelaskan bahwa massa dan energi adalah dua hal yang setara (Petrucci, 1995). Jika massa sebuah objek diketahui, dengan mengalikannya pada kuadrat kecepatan cahaya, materi akan berubah menjadi energi. Einstein menunjukkan bahwa cahaya, yang sampai saat itu masih dianggap sebagai sebuah gelombang, berperilaku seperti sebuah partikel.

Cahaya adalah salah satu bentuk saja dari materi. Hal dibuktikan di tahun 1919, ketika ditunjukkan bahwa cahaya dibelokkan oleh gaya gravitasi. Louis de Broglie kemudian menunjukkan bahwa materi yang dianggap hanya terdiri dari partikel selalu memiliki pula sifatsifat gelombang (Dampier, 1984). Batasan antara materi dan energi telah dihapuskan untuk selamanya. Materi dan energi adalah sama. Argumen yang mendominasi fisika partikel selama bertahun-tahun, apakah partikel sub-atomik seperti foton dan elektron adalah partikel atau gelombang akhirnya diselesaikan oleh mekanika kuantum. Menegaskan bahwa partikel subatomik dapat dan berperilaku sebagai partikel dan gelombang sekaligus. Seperti sebuah gelombang, cahaya menghasilkan interferensi, tapi, sebuah foton cahaya juga dapat memantul ketika membentur sebuah elektron, yang berarti berlaku seperti sebuah partikel.

$\mathrm{Hal}$ ini bertentangan dengan logika formal. Bagaimana mungkin "nalar-sehat" menerima bahwa sebuah elektron dapat ada di dua tempat sekaligus? Atau bahkan bergerak, pada 
kecepatan yang tinggi tak terbayangkan, ke berbagai jurusan sekaligus? Upaya untuk menjelaskan gejala kontradiktif dari dunia sub-atomik dengan cara-cara logika formal akan membawa untuk meninggalkan pemikiran rasional sama sekali. Jika pikiran dari Bohr atau Einstein membuat kita terkagum-kagum dengan kekuatannya, bagaimana kita mulai memuja keagungan Tuhan yang menciptakannya?" Hukum-hukum mekanika kuantum akan runtuh di hadapan "nalar-sehat" (yaitu, logika formal), tapi akan berkesesuaian benar dengan materialisme dialektik. Ambillah, misalnya, pandangan tentang sebuah titik. Seluruh geometri tradisional diturunkan dari satu titik, yang selanjutnya menjadi garis, bidang, kubus, dsb. Walau demikian, pengamatan yang lebih rinci menunjukkan bahwa sebuah titik tidaklah memiliki keberadaan mandiri.

\section{Annihilasi Materi}

Jauh sebelum ditemukannya relativitas, ilmu pengetahuan telah menemukan dua prinsip dasar-kekekalan energi dan kekekalan massa. Hukum yang pertama ditemukan oleh Leibniz di abad ke-17, dan kemudian dikembangkan di abad ke-19 sebagai sebuah hasil dari prinsipprinsip mekanika (Dampier, 1984). Jauh sebelum itu, manusia jaman purba telah menemukan secara praktek prinsip kesetaraan antara kerja dan panas, ketika ia membuat api melalui gesekan, dengan demikian mengubah sejumlah tertentu energi (kerja) menjadi panas. Pada awal abad ke-19, ditemukan bahwa massa hanyalah salah satu bentuk energy (Aoki et al., 2006). Satu partikel materi yang tidak lain adalah energi, yang sangat terkonsentrasi dan terlokalisasi. Jumlah energi yang terkonsentrasi dalam sebuah partikel berbanding lurus dengan massanya, dan jumlah total energi adalah selalu tetap.

Hilangnya sejumlah energi tertentu akan selalu diimbangi dengan didapatnya sejumlah energi dalam bentuk lain. Sambil terus mengubah bentuknya, bagaimanapun, energi akan tetap sama selamanya. Revolusi yang disebabkan oleh Einstein adalah satu pembuktian bahwa massa itu sendiri mengandung jumlah energi yang luar biasa (Hayashi, 2017). Kesetaraan massa dan energi dinyatakan dalam persamaan $\mathrm{E}=\mathrm{mc}^{2}$ di mana c melambangkan kecepatan cahaya (sekitar 186.000 mil per detik atau $300.000 \mathrm{~km}$ per detik), E adalah energi yang terkandung dalam sebuah benda diam, dan $\mathrm{m}$ adalah massanya. Energi yang terkandung dalam massa $\mathrm{m}$ adalah setara dengan massa ini yang dikalikan kuadrat dari kecepatan cahaya yang luar biasa besar itu.

Massa adalah bentuk energi yang teramat terkonsentrasi, kekuatan yang boleh digambarkan oleh fakta bahwa energi yang dilepaskan dalam sebuah ledakan atom dihasilkan ketika hanya $10 \%$ dari massanya diubah menjadi energi. Biasanya, energi raksasa yang terkunci dalam materi ini tidak mewujud, dan dengan demikian tidak diperhatikan oleh manusia. Tapi jika proses di dalam inti atom mencapai satu titik kritis, sebagian energi akan dilepaskan, sebagai energi kinetik. Karena massa hanyalah salah satu bentuk energi, baik materi maupun energi tidak dapat diciptakan maupun dihancurkan (Kuhn, 1993). Bentuk-bentuk energi, di pihak lain, sangatlah beragam. Sebagai contoh, ketika proton di permukaan matahari bersatu untuk membentuk inti atom helium, energi nuklir dilepaskan. Pertama-tama ini mungkin nampak sebagai energi kinetik dari gerak inti atom, yang kemudian memberi sumbangan pada energi panas yang dilepaskan matahari. Sebagian energi ini dipancarkan dari matahari dalam bentuk foton, mengandung partikel-partikel energi elektromagnetik.

Partikel-partikel ini, pada gilirannya, diubah oleh proses fotosintesis menjadi energi kimia potensial yang tersimpan dalam tumbuhan, yang pada giliran selanjutnya, diserap oleh manusia dengan memakan tanaman, atau hewan yang hidup dari memakan tanaman, untuk menyediakan kehangatan dan energi bagi otot, aliran darah, otak, dan lain-lain. Hukum-hukum fisika klasik secara umum tak dapat diterapkan pada tingkat sub-atomik (Keenan, 1980). Walau demikian, terdapatlah satu hukum yang tidak mengenal pengecualian di alam -hukum kekekalan energi. Para fisikawan tahu bahwa baik muatan positif maupun negatif tidaklah dapat diciptakan dari sebuah ketiadaan.

Fakta ini dinyatakan dalam hukum kekekalan muatan listrik. Dengan demikian, dalam proses untuk menghasilkan partikel Beta $(\beta)$, lenyapnya neutron (yang tidak bermuatan) menimbulkan sepasang partikel yang muatannya berlawanan -proton yang bermuatan positif dan elektron yang bermuatan negative (Vanier, 2005). Bersama-sama, kedua partikel baru itu memiliki muatan gabungan setara dengan nol. Jika dilakukan proses kebalikannya, ketika sebuah proton memancarkan sebuah positron dan berubah menjadi neutron, muatan dari partikel asli (proton) adalah positif dan partikel yang dihasilkan (neutron dan posittron), bersama-sama, juga bermuatan positif (Aoki et al., 2006). Dalam seluruh perubahan yang beraneka ragam ini, hukum kekekalan muatan dipatuhi secara ketat, seperti halnya hukum- 
hukum kekekalan yang lain. Tidak secuilpun energi yang diciptakan atau dihancurkan. Ketika sebuah elektron dan anti-partikelnya, positron, saling menghancurkan, massa mereka "hilang", yaitu, diubah menjadi dua partikel cahaya (foton) yang terbang berhamburan ke arah yang berlawanan. Walau demikian, keduanya memiliki energi total yang sama dengan kedua partikel yang telah bersatu untuk menghasilkan mereka. Kesetaraan massa-energi, momentum linear dan muatan listrik dipelihara dengan ketat.

Gejala ini sama sekali tidak sama dengan pelenyapan dalam makna penghancuran. Materi dan energi (yang hanya merupakan dua cara untuk menyatakan hal yang sama) tidak akan pernah dapat diciptakan maupun dihancurkan, hanya diubah. Foton adalah sama materialnya dengan elektron atau positron. Massa terus menerus diubah menjadi energi (termasuk cahaya - foton) dan energi menjadi massa. "Penghancuran" sebuah positron dan elektron menghasilkan sepasang foton, tapi kita juga melihat proses yang kebalikannya: ketika dua foton bertemu, sebuah elektron dan sebuah positron dapat dihasilkan, asalkan foton itu mengandung energi yang cukup (Trefil, 1990). Ketika sebuah foton menghantam inti atom, ia berhenti mengada sebagai sebuah foton. la hilang, tapi menyebabkan satu perubahan di dalam atom - sebuah elektron meloncat dari satu orbit yang lebih rendah ke orbit lain yang lebih tinggi tingkatan energinya. Di sini juga proses yang kebalikannya terjadi. Ketika sebuah elektron melompat ke orbit yang berenergi lebih rendah, sebuah foton muncul.

\section{Batu Penyusun Materi}

Telah beabad-abad para ilmuwan berusaha dengan sia-sia untuk menemukan "batu penyusun materi" -partikel pamungkas yang terkecil. Seratus tahun yang lalu, mereka pikir mereka telah menemukannya dalam bentuk atom (dalam bahasa Yunani, berarti "sesuatu yang tak dapat dibagi lagi") (Dampier, 1984). Penemuan partikel-partikel subatomik memaksa fisika untuk merambah lebih dalam ke dalam struktur materi. Di tahun 1928, para ilmuwan berkhayal bahwa mereka telah menemukan partikel yang terkecil, yang disebut proton, elektron dan foton. Seluruh dunia material dianggap tersusun dari ketiga partikel tersebut. Selanjutnya, ini juga diruntuhkan oleh penemuan neutron, positron, deuteron, dan serombongan partikel lain, yang semakin kecil, dengan keberadaan yang semakin sekejap - neutrino, pi-meson, mu-meson, kmeson, dan banyak lagi yang lain (Trefil, 1990). Umur dari beberapa partikel ini sangat kecil mungkin sepersejuta detik- sehingga mereka digambarkan sebagai "partikel virtual"- sesuatu yang sama sekali tak terbayangkan sebelum datangnya jaman kuantum.

Tauon berumur hanya seperbilyun detik, sebelum luruh menjadi muon, dan kemudian menjadi electron (Trefil, 1990). Pion yang netral lebih pendek lagi masa hidupnya, luruh dalam waktu kurang dari sepertrilyun detik untuk membentuk sepasang partikel sinar gamma. Walau demikian, partikel-partikel gamma ini hidup sampai usia lanjut, dibandingkan dengan yang lainlain yang hanya hidup selama seperseratus mikrodetik. Beberapa yang lain, seperti partikel sigma yang netral, luruh setelah seper seratus milyar detik. Di tahun 1960-an, bahkan hal ini masih dikalahkan oleh penemuan partikel yang lebih pendek lagi masa hidupnya sehingga keberadaannya hanya dapat disimpulkan dari keharusan mereka untuk meluruh agar terbentuk beberapa partikel turunan yang telah diketahui. Masa paro-hidup dari partikel-partikel ini berada di kisaran seper beberapa trilyun detik. Mereka dikenal sebagai partikel resonan. Dan inipun belum lagi akhir ceritanya. Lebih dari seratus lima puluh partikel lain ditemukan kemudian, yang kemudian dikenal sebagai hadron.

Seorang fisikawan Amerika, Murray Gell-Mann, dalam upayanya untuk menjelaskan struktur partikel-partikel sub-atomik, telah mempostulatkan beberapa partikel yang lain lagi, yang lebih mendasar, quark, yang lagi-lagi dicanangkan sebagai "batu penyusun materi pamungkas" (Trefil, 1990). Gell-Mann berteori bahwa terdapat enam jenis quark dan bahwa keluarga quark adalah paralel dengan keenam anggota keluarga partikel yang lebih ringan, yang disebut lepton. Semua materi kini dianggap terdiri dari duabelas partikel penyusun. Namun, bahkan bentuk materi paling dasar yang dikenal ilmu pengetahuan ini masih juga mengandung kualitas kontradiktif yang sama dengan apa yang kita amati di seluruh jagad raya, bersesuaian dengan hukum dialektik tentang kesatuan dari hal-hal yang bertentangan. Quark juga hadir dalam pasangan-pasangan, dengan muatan postitif dan negatif, sekalipun, dengan anehnya, dinyatakan dalam (Aoki et al., 2006; Vanier, 2005). Quark kini dianggap sebagai yang pamungkas dari kedua belas "batu penyusun" sub-atomik yang katanya menyusun segala materi di jagad raya.

Hal yang menarik adalah inilah potongan materi yang terakhir yang akan pernah kita kenal, seperti yang diramalkan oleh kosmologi dan Model Standard dari fisika partikel. David Schramm melaporkan, 'Inilah potongan teka-teki yang terakhir' (Trefil, 1990). Jadi, quark adalah 
"partikel pamungkas". la disebut fundamental dan tidak memiliki struktur lagi di dalamnya. Tapi hal yang sama telah pula diramalkan di masa lalu untuk atom, lalu proton, dan sebagainya dan seterusnya. Dengan cara yang sama, kita dapat dengan yakin meramalkan penemuan bentukbentuk yang lebih "fundamental" lagi dari materi di masa depan. Fakta bahwa keadaan pengetahuan dan teknologi sekarang tidak mengijinkan untuk menentukan sifat-sifat quark tidaklah kemudian mewajibkan ilmuwan untuk mengatakan bahwa ia tidak memiliki struktur lagi di dalamnya. Sifat dan ciri quark masih harus menunggu telaah lebih lanjut, dan tidak ada alasan untuk menganggap bahwa hal ini tidak akan mungkin tercapai, bahwa mustahil bagi kita untuk merambah ke kedalaman struktur materi yang tidak berujung.

\section{Kesimpulan}

Simpulan artikel ini, Banesh Hoffman dalam sebuah karya tentang revolusi kuantum, mengungkapkan bahwa seberapa sering lagi kita harus mengagumi karya Tuhan yang luar biasa, yang menciptakan langit dan bumi dari sebuah hakikat primat dari sebuah rincian yang demikian indah sehingga dengannya la dapat menciptakan otak dan pikiran yang bernyala dengan berkah kemampuan meramal yang ilahiah untuk menerobos misteri ciptaan-Nya sendiri. Inilah cara yang selalu ditempuh ilmu pengetahuan dalam kemajuannya. Dengan memahami hakekat ilmu, manusia dengan akalnya mencoba mengungkap tabir dari berbagai perspektif-perspektif ilmu, kemungkinan-kemungkinan pengembangannya, keterjalinannya antar ilmu, simplifikasi dan artifisialitas ilmu dan lain sebagainya, yang vital bagi penggarapan ilmu itu sendiri. Lebih dari itu, dengan filsafat ilmu mendorong manusia untuk memahami kekuatan serta keterbatasan metode, prasuposisi ilmu, logika validasi, struktur pemikiran ilmiah dalam konteks dengan realitas sedemikian rupa sehingga seorang ilmuwan dapat terhindar dari kecongkakan serta kerabunan intelektualnya. Halangan yang tadinya dianggap mustahil dipecahkan oleh satu generasi dijungkirkan oleh generasi berikutnya, dan demikian seterusnya sepanjang jaman. Seluruh pengalaman lampau memberi segala alasan untuk percaya bahwa proses dialektikal atas kemajuan pengetahuan manusia ini adalah sama tak berujungnya seperti jagad raya itu sendiri.

\section{Daftar Pustaka}

Aoki, Y., Endrodi, G., Fodor, Z., Katz, S. ., \& Szabo, K. . (2006). The Ororder of The Quantum Chromodynamics Transition Predicted by The Standard Model of Particle Physics. Germany: Nature. https://doi.org/10.1038/nature05120

Bernal, J. . (1981). The Natural Sciences In Our Time (3rd ed.). Massachusets: The MIT Press Cambridge.

Bruton, J. . (1996). The Story of Western Science. New York: Cambridge University Press.

Dampier, W. . (1984). A History of Science (4th ed.). New York: Cambridge University Press.

Farida ,Ida (2011) Analisis Sejarah Perkembangan Model Atom Berdasarkan Paradigma Kuhn. Jurnal Program Studi Pendidikan Kimia UIN Sunan Gunung Djati Bandung.

Feinberg, G. (1990). Partikel Elementer: Ilmu pengetahuan Populer (5th ed.). Jakarta: PT Widya Dara.

Hayashi, M. (2017). Quantum Information Theory (Second Edi). Berlin, Germany: SpringerVerlag Berlin Heidelberg. https://doi.org/10.1007/978-3-662-49725-8

Hodeson, L. (2012). Teori Kuantum (5th ed.). Jakarta: PT. Widya Dara.

Keenan, C. W. (1980). General College Chemistry (6th ed.). New York: Harper \& Row Publishers, Inc.

Kuhn, T. (1993). Peran Paradigma Dalam Revolusi Sains. (S. Tjun, Ed.) (2nd ed.). Bandung: PT. Remaja Rosda Karya. 
Mc Avoy, J. ., \& Zarate, O. (1996). Mengenal Teori Kuantum Untuk Pemula. (B. Ahmad, Ed.). Jakarta: PT Widya Dara.

Musthafa, K. (2000). Alam Semesta Dan Kehancurannya Menurut Al-Qur'an Dan IImu Pengetahuan. Bandung: Al-Ma'arif.

Ngafifi , M. (2014). Kemajuan Teknologi Dan Pola Hidup Manusia Dalam Perspektif Sosial Budaya. Jurnal Pembangunan Pendidikan: Fondasi dan Aplikasi

Petrucci, R. H. (1995). General Chemistry: Principles And Modern Applications (4th ed.). New York: Collier Nac millan Inc.

Poedjiadi, A. (1987). Sejarah dan filsafat sains. (Bima, Ed.) (1st ed.). Jakarta: Proyek Pengembangan Lembaga Pendidikan Tenaga Kependidikan.

Stephen F, M. (1992). A History of The Sciences (New Revise). London: Abelard-Schuman Ltd.

Sabarni (2014). Atom Dan Molekul Berdasarkan IImu Kimia Dan Perspektif Al-Quran. Fakultas Tarbiyah dan Keguruan UIN Ar-Raniry Banda Aceh. Lantanida Journal, Vol. 2 No. 2, 2014

Trefil, J. (1990). Kuarka (5th ed.). Jakarta: PT Widya Dara.

Vanier, J. (2005). Atomic clocks based on coherent population trapping: a review, 442, 421422. https://doi.org/10.1007/s00340-005-1905-3 